University of Nebraska - Lincoln

DigitalCommons@University of Nebraska - Lincoln

Nebraska Cooperative Fish \& Wildlife Research Nebraska Cooperative Fish \& Wildlife Research Unit -- Staff Publications

2010

\title{
Evaluating food availability and nest predation risk as sources of bias in aural bird surveys
}

\author{
Bruce A. Robertson \\ University of Montana - Missoula, brucerobertson@hotmail.com \\ Richard L. Hutto \\ University of Montana - Missoula \\ Joseph J. Fontaine \\ University of Nebraska-Lincoln, jfontaine2@unl.edu
}

Follow this and additional works at: https://digitalcommons.unl.edu/ncfwrustaff

Part of the Other Environmental Sciences Commons

Robertson, Bruce A.; Hutto, Richard L.; and Fontaine, Joseph J., "Evaluating food availability and nest predation risk as sources of bias in aural bird surveys" (2010). Nebraska Cooperative Fish \& Wildlife Research Unit -- Staff Publications. 84.

https://digitalcommons.unl.edu/ncfwrustaff/84

This Article is brought to you for free and open access by the Nebraska Cooperative Fish \& Wildlife Research Unit at DigitalCommons@University of Nebraska - Lincoln. It has been accepted for inclusion in Nebraska Cooperative Fish \& Wildlife Research Unit -- Staff Publications by an authorized administrator of DigitalCommons@University of Nebraska - Lincoln. 


\title{
Evaluating food availability and nest predation risk as sources of bias in aural bird surveys
}

\author{
Bruce A. Robertson, ${ }^{1,2}$ Richard L. Hutto, ${ }^{1}$ and Joseph J. Fontaine ${ }^{1}$ \\ ${ }^{1}$ Avian Science Center, University of Montana, Missoula, Montana 59812, USA
}

Received 28 March 2010; accepted 29 July 2010

\begin{abstract}
The use of aural surveys to estimate population parameters is widespread in avian studies. Despite efforts to increase the efficacy of this method, the potential for ecological context to bias population estimates remains largely unexplored. For example, food availability and nest predation risk can influence singing activity independent of density and, therefore, may bias aural estimates where these ecological factors vary systematically among habitats or other categories of ecological interest. We used a natural fire event in a mixed-conifer forest that experienced variation in fire severity (low, intermediate, and high) to determine if aural surveys produce accurate density estimates of Dark-eyed Juncos (Junco hyemalis) independent of ecological context. During the first 2-yr postfire, we censused junco populations in each burn type with intensive spot-mapping and nest searching, locating 168 nests. Simultaneously, we conducted fixed-radius point-count surveys and estimated food availability and nest predation risk in each burn type to test whether ecological context may influence aural detection probability independent of actual density. We found no difference in nesting densities among patches burned at different severity. Arthropod food availability was inversely related to fire severity during the first postfire breeding season, but increased to higher levels across all severities during the second. In both years, aural detections were significantly greater in intermediate severity patches that consistently represented the habitat with the lowest nest predation risk. These results suggest that nest predation risk may significantly bias aural estimates of avian populations. Although traditional aural survey methods such as the Breeding Bird Survey measure habitat attributes, our findings highlight the difficulty in assessing relevant covariates in estimates of avian population. Future research must consider the potential for nest predation and other ecological factors to drive interannual or interhabitat variation in avian population estimates independent of true changes in population size.
\end{abstract}

RESUMEN. Evaluación de la disponibilidad de alimento y el riesgo de depredación de los nidos como una fuente de sesgos en los censos auditivos de aves

El uso de censos auditivos para estimar parámetros poblacionales es bastante utilizado en estudios de aves. A pesar de los esfuerzos para incrementar la eficacia de estos métodos, los sesgos potenciales creados por contextos ecológicos para estimar poblaciones todavía permanecen inexplorados. Por ejemplo, la disponibilidad de alimento y el riesgo de depredación de los nidos pueden influenciar la actividad vocal independientemente de la densidad, por lo cual, puede crear sesgos en los estimados auditivos en donde estos factores ecológicos varían de forma sistemática entre hábitat u otras categorías de interés ecológico. Usamos un evento natural de fuego en un bosque mixto de coníferas que experimento variación en la severidad del fuego (baja, intermedia y alta) para determinar si los censos auditivos producen una estimación precisa de la densidad de Junco hyemalis independientemente del contexto ecológico. Durante los primeros dos años después del fuego, censamos poblaciones de J. hyemalis en cada tipo de quema con intenso mapeo de detecciones y búsqueda de nidos, localizando 168 nidos. Simultáneamente, realizamos censos con puntos de conteo de radios fijos y estimamos la disponibilidad de alimento y riesgo de depredación de nidos en cada tipo de quema, para probar si el contexto ecológico puede afectar la probabilidad de detecciones auditivas independiente de densidades reales. No encontramos diferencias en densidades de anidación entre parches quemados a diferentes intensidades. Las disponibilidad de alimento de artrópodos estuvo inversamente relacionada con la intensidad del fuego durante la primera temporada reproductiva después del fuego, pero incremento a niveles mayores en todas las intensidades de fuego durante la segunda temporada. En ambos años, detecciones auditivas fueron significativamente mayores en parches con intensidad intermedia los cuales consistentemente representaron el hábitat con los más bajos niveles de riesgo de depredación. Los resultados siguieren que el riesgo de depredación sesga significativamente los estimados de detección auditiva en poblaciones de aves. A pesar de que métodos tradicionales de estimaciones como censos de aves durante la época reproductiva miden atributos del habita, nuestros resultados remarcan la dificultad de acceder covariables relevantes en estimativos de poblaciones de aves. Futuras investigaciones deberían considerar el potencial de la depredación de nidos y otros factores ecológicos que influyen variación entre

\footnotetext{
${ }^{2}$ Corresponding author. Current address: Smithsonian Migratory Bird Center, National Zoo, Washington,
} D.C. 20008. Email: brucerobertson@hotmail.com 
años o entre hábitat en los estimados de poblaciones de aves independientemente del verdadero cambio en el tamaño poblacional.

Key words: bird survey, detection bias, food limitation, nest predation, point count

Aural surveys, such as point counts and line transects, are commonly used to assess avian species composition and provide estimates of avian density and abundance (Ralph et al. 1995, Thompson 2002). The validity of management and policy decisions based upon such surveys depends on the assumption that detection probability (the probability of detecting a bird, given it is present) is similar across sites that may include a range of habitat types and abiotic conditions (Alldredge et al. 2007a), and that any additional biases are identified and eliminated. Consequently, variation in the detection of individuals due to the abundance of birds must be separated from variation in detection rates due to behavioral, physical, or other factors that affect the ability of researchers to detect them.

A decrease in detectability with increasing distance from the observer (Reynolds et al. 1980) is perhaps the most important source of bias addressed when analyzing count data (reviewed by Johnson 2008), but there are several additional factors that might also affect detectability. These include differences in observer ability (Emlen and DeJong 1981, Sauer et al. 1994), ambient noise levels (McCallum 2005), time of season (Wilson and Bart 1985, Diefenbach et al. 2007), reproductive status (Diehl 1981, Wilson and Bart 1985), time of day (Sheilds 1977, Kessler and Milne 1982), weather conditions (O'Connor and Hicks 1980, Emlen and DeJong 1981) and vegetation type (Scott et al. 1981, Schieck 1997). Investigators can try to model the effects of multiple sources of bias simultaneously (Marques et al. 2007), but this is difficult (Johnson 2008). Given that the sample sizes necessary to model the effects of all sources of bias simultaneously are prohibitively large, researchers must be selective about which variables to include when attempting to model bird detectability.

Differences in singing rate are thought to be an important determinant of detection probability (Alldredge et al. 2007a). Singing rates vary with physiological condition (Nystrom 1997, Thomas and Cuthill 2002), pairing status (Hanski and Laurila 1993, Merilä and Sorjonen
1994), paternal effort (Greig-Smith 1982, Welling et al. 1997), social rank (Otter et al. 1997), breeding density (Penteriani 2003), food availability (Gottlander 1987, Grava and Otter 2009), and nest predation risk (Hoi-Leitner et al. 1995, Fontaine and Martin 2006). Given that $\geq 90 \%$ of point-count detections typically result from aural cues (Carey et al. 1990), the potential for bias due to differences in singing rates is substantial. However, whether ecologically mediated differences in singing rate represent systematic error or true biases remains unclear (but see McShea and Rappole 1997).

Singing rates are ultimately limited by the availability of energy provided by food resources (Gottlander 1987, Grava and Otter 2009). However, lower predation rates should favor increases in singing activity because males should be less likely to attract predators to their nest sites and, therefore, can spend less time on nest defense and more time foraging (Komdeur and Kats 1999, Martin et al. 2000). Also, variation in singing rates among males can reflect male advertisement of territory quality (Hoi-Leitner et al. 1995), including the local abundance of nest predators (Fontaine and Martin 2006). As a consequence, spatial variation in both food availability and nest predation can bias estimates of avian density and abundance by influencing singing behavior. We took advantage of a wildfire that led to spatial and temporal variation in two important environmental factors known to influence the singing rates of songbirds: food availability and the risk of nest predation. To determine if one or both of these factors can systematically bias detections, we examined their effects on the singing rates of territorial male Dark-eyed Juncos (Junco hyemalis).

Wildfires shape floral and faunal communities throughout western North America (Habeck and Mutch 1973, Arno and Allison-Bunnel 2002), and can influence the local distributions of species by creating a mosaic of patch types when fire severity and extent vary spatially (Platt and Connell 2003, Turner et al. 2003). For example, rodents are known to be important nest predators in the Northern Rockies 
and the abundance of several species has been linked to variation in fire severity (Stuart-Smith and Hayes 2003, Zwolak and Foresman 2007, 2008). By reducing vegetation density and structure, wildfires reduce small mammal diversity and the abundance of squirrels (Tamias spp.), shifting small-mammal communities toward a greater abundance of deer mice (Peromyscus maniculatus; Zwolak and Foresman 2007). By shifting the distribution and abundance of small-mammals, wildfire can create variation in nest predation risk across forest patches burned at different levels of severity (Krefting and Ahlgren 1974, Stuart-Smith and Hayes 2003). Robertson (2009) found that nest predation risk for Dark-eyed Juncos was consistently lower in forest patches burned at intermediate severity than in patches burned at low or high severity.

Wildfire is also known to reduce the diversity and abundance of terrestrial arthropods for at least 1-yr postfire (Wikars and Schmimel 2001, Short and Negron 2003). Arthropods are particularly important food source for juncos (Nolan et al. 2002) during the breeding season. However, the availability of arthropod prey for juncos in our study area may be limited during the breeding season, particularly in patches burned at high severity and early in the breeding season of the first postfire year (Robertson 2009). Thus, we predicted that food availability would be greater in patches burned at lower severity, at least during the first postfire year.

Assuming that food availability and nest predation risk vary independently across fire severities, natural variation in postfire burn severity can be used to examine relationships between food availability, nest predation, and number of individuals detected during surveys. Assuming the benefits of choosing high-quality territories are additive, we predicted that more singing males would be detected in areas with the greatest food availability and lowest nest predation risk. By comparing males occupying sites within burned forest with high food availability and high nest predation risk and males occupying sites with low food availability and low nest predation risk, we can examine the relative importance of nest predation and food availability in estimates of avian abundance. Covariation between the detection of individuals and food availability or nest predation risk will indicate whether site specific differences in these ecolog- ical factors can systematically bias the detection of individuals and result in unreliable estimates of relative abundance.

\section{METHODS}

Dark-eyed Juncos are territorial, socially monogamous passerines that forage and typically nest on the ground. Only males sing, and they sing most frequently during the breeding season, likely to defend territories and attract mates (Hostetter 1961). From April to August 2004-2005, we used standardized point counts to survey singing male juncos breeding within the boundaries of the 2858-ha Black Mountain fire of 2003. Located in the Lolo National Forest in western Montana, our study area was dominated by mixed-conifer forest stands of ponderosa pine (Pinus ponderosa), lodgepole pine (Pinus contorta), and western larch (Larix occidentalis). We established a 300-ha subplot to use as a focal study area based on its narrow elevation range $(1280-1341 \mathrm{~m})$ and the presence of patches that burned to different degrees.

We used natural variation in burn severity to increase the chance of finding systematic variation in nest predation risk and food availability, and we then examined the likelihood of detecting birds known to occupy specific territories. Typical of mid-elevation fires in the northern Rockies, the Black Mountain fire burned unevenly, creating a mosaic of forest patches that were either unburned or that burned at one of three categories of burn severity. Local burn severity of forest patches was defined based on a modified version of the composite burn index (Ryan and Noste 1985, Key and Benson 2005): (1) Low severity-Light charring with up to moderate consumption of downed fuels including litter and duff. Regenerated herbs and grass dominate understory. Shrubs and saplings show little mortality. Tree overstory is not scorched or blackened, and tree charring remains $<2 \mathrm{~m}$, (2) Intermediate severity-Ground is deeply charred with small twigs, litter, and duff largely consumed. Increased densities of new serals (fireweed and lodgepole pine) are present, but some prefire herbs and shrubs persist. Most tree crowns are blackened or largely scorched, but a few green crowns remain, and (3) High severity-Major portions of large downed fuels, litter, and duff consumed. Substantial amounts 
of mineral soil are exposed. Prefire herbs and shrubs are essentially absent with low-density patches of seral species found in the understory. Significant portions of overstory are consumed, including most fine branching in crowns.

Nest predation rate. We began daily surveys for juncos in mid-April, well before the first nest dates for this species in the region (see below). We located and monitored nests to determine nest predation rates, following standard techniques (Martin and Guepel 1993). We monitored each junco territory for the entire breeding season and searched for all nests from late April to mid-August 2004 and 2005. To avoid observer bias, we alternated searching for nests individually and in small teams, and searched plots for nests by holding effort constant across burn severities. Most nests (68\%) were located during nest building, egg laying, or incubation. We monitored nests every 3-4 d. We considered a nest to be successful if at least one young was observed outside of the nest or parents were seen carrying food after nests were empty.

Characteristics of nest sites were measured within 2 weeks of the completion of a nesting attempt. To control for the effects of nest concealment on nest predation, nest concealment was quantified by estimating the percentage of each nest visible from $1 \mathrm{~m}$ in each of the four cardinal directions and $1 \mathrm{~m}$ above nests. All five measurements were averaged for a single index of concealment for each nest. We estimated the dominant burn severity in two nest-centered circular plots $(50-\mathrm{m}$ and $100-\mathrm{m}$ radius, respectively). Assessments of burn severity at both radii were highly correlated $\left(r^{2}=0.96\right)$ and, because the 50 -m radius assessment is more conservative relative to the distribution of fire severity effects, we used those data in our analyses.

Food availability. During the breeding season, arthropods are the primary food source for adult and nestling juncos (Nolan et al. 2002). If food availability influences singing, then singing rates may reflect the current or anticipated availability of food. Consequently, assessing habitat-specific food availability is important not only during settlement, but later in the breeding season. We sampled terrestrial arthropod abundance during the first week of May and again during the last week of June to assess within-habitat consistency in food availability across the breeding season. Because juncos are ground-foragers (Nolan et al. 2002), we focused our sampling efforts on the forest floor. In both years, we randomly selected 21 sampling locations in each burn severity category (low, intermediate, and high). At each sampling location, we arranged a crosswise array of five 296-ml plastic cups buried level with the surface of the ground and placed at $1-\mathrm{m}$ intervals. We filled cups halfway with unscented castile soap and water to detain any captured arthropods, and opened traps for the same set of 5-d periods in both years. At the end of each sampling period, the contents of each trap were fine-sieved and transferred to plastic bags (Whirl-Pak; Nasco, Modesto, CA) containing $95 \%$ ethanol. Samples were oven dried $\left(60^{\circ} \mathrm{C}\right.$ for $4 \mathrm{~h}$ ) and weighed.

Surveys of singing males. In heavily vegetated habitats, such as forests, detections are primarily auditory (Scott et al. 1981) and whether or not an individual is detected by auditory surveys depends on the probability that a bird sings or calls during a count (Farnsworth et al. 2002). For Dark-eyed Juncos, the likelihood of being detected by an observer is positively related to singing rate (Titus et al. 1997). Although junco songs are audible to human observers at distances up to $250 \mathrm{~m}$ (Nolan et al. 2002), the effective detection radius for Dark-eyed Juncos (the distance where the probability of detection is 0.5 ) in dense, closed-canopy forest was $49.2 \mathrm{~m}$ (Alldredge et al. 2007b). Although a 1-min aural sampling period was sufficient to detect differences in singing rates in response to experimentally removing potential nest predators in an unburned system (Fontaine and Martin 2006), we chose a 5-min sampling period to increase the likelihood of detecting all individuals present in a count area, thereby making our effect sizes more conservative.

We estimated the relative number of singing males detected in forest patches of differing burn severity using a series of 5 -min point counts with a fixed 50-m radius. Juncos only seen and singing birds whose distance could not be verified visually were not tallied. The distance to birds observed while vocalizing were estimated by noting their position relative to distance-accurate landmarks. The position of unseen juncos whose singing bouts continued after the survey period was verified by approaching and observing the juncos. Counter-singing was considered confirmation that songs were 
coming from more than one male within a count circle. We established a series of four pointcount transects across the study area and stopped every $100 \mathrm{~m}$ along each transect and tallied the number of singing males detected within each point count radius. Ten points in areas of each burn severity were resampled five times in both postfire years throughout the period of settlement and pairing. Transects were sampled between sunrise and 10:00, and each transect was sampled twice per year during the early nesting period.

Territory density and breeding status. To assess whether habitats of different burn severities differed in bird density, we mapped territories by locating counter-vocalizing territorial males (Ralph et al. 1993) beginning in late April of each year prior to the first recorded nest initiation. The location and movements of individual singing and counter-singing males and other aggressive interactions between territorial males were marked on a high-resolution aerial photo of the study area (1:700). To improve accuracy of mapped locations, nests and conspicuous landmarks in the study area were located using handheld GPS units and placed on georectified handheld maps. Observations made from the day the first nest was located to the day the last nestlings fledged to estimate territory area, defined as the minimum convex polygon (MCP) enclosing the locations where territorial disputes, singing, and countersinging occurred. To determine the minimum number of observations necessary to accurately delineate a territory, we first analyzed a subset of territories and graphed polygon area versus number of song perches for randomly subsampled clusters of song perches. Coordinates associated with territorial males were entered into a geographic information system to calculate the area of each territory using the minimum convex polygon method (Odum and Kuenzler 1955). We analyzed a subset of 15 territories for which 113 mapped song perches were available. The plot of polygon area versus number of song perches reached an asymptote at the 30-perch threshold. Consequently, we based territory size estimates on MCPs drawn around 30 mapped locations randomly selected from the pool of mapped song perches for each territory. For all territories, we visually estimated the burn severity (see Methods above for criteria) at its centroid. Severity estimates were based on fire effects within a 50-m radius because estimates based on 100-m radii occasionally overlapped other territories.

Breeding status and breeding density can reflect habitat quality (Fretwell 1972, Fontaine and Martin 2006), but may also influence singing behavior independently (Penteriani 2003). To control for potential confounding effects, we examined breeding status, territory size, and territory density for all burn types. Dark-eyed Juncos are not known to increase singing rates when mates or neighboring females are fertile (Titus et al. 1997), but we examined annual and severity-specific variation in the timing of pairing because competition among males for mates can affect singing rates. To determine pairing status, we began daily visits to territories on 18 April. We visited territories of all singing males a minimum of 10 times prior to initiation of their first nests and observed males for $15 \mathrm{~min}$. Males were considered paired if a nest or evidence of nest (e.g., feeding fledglings) was found on its territory or if observed with a female.

Statistical analyses. We used ANOVA to determine if the average date of pairing and first nest initiation in each territory differed among burn severities and postfire years, and to compare territory sizes among treatments and years. Territory density estimates were calculated as the total number of territories in areas of each burn severity divided by the total area of each burn severity in the study area (Clark and Bobbe 2006). We estimated daily nest predation rate using a logistic-exposure model with a binomial response distribution (PROC GENMOD, SAS Institute 1999, see Shaffer 2004) with year as an independent variable and concealment as a covariate. We also controlled for possible seasonal effects (Nilsson 1989, Hochachka 1990) by including date as an independent variable in the analysis. We tested for differences in daily predation rate among burn severities using a $\chi^{2}$ goodness-of-fit test. Estimates and their confidence limits were back transformed from the logit scale for presentation (proportion $=$ $\left.e^{\text {estimate }} /\left[1+e^{\text {estimate }}\right]\right)$. We used $\alpha=0.05$ as the level of statistical significance. We examined differences in terrestrial arthropod biomass across burn severities and years using an ANCOVA. We used ANOVA to examine variation in the average number of singing males detected across the survey period, with year and burn severity as independent variables. Tukey's LSD test was used for all post hoc tests. 


\section{RESULTS}

Nest predation. We located 168 nests (low-severity $=49$, intermediate-severity $=59$, and high-severity $=60$ ) over 2 yrs representing 1745 exposure days. We found no difference in the average date of first nest initiation for juncos in areas that differed in burn severity (severity: $F_{2,58}=1.8, P=0.17$; year: $\mathrm{F}_{1,58}=$ $2.1, P=0.15)$. Daily nest predation rate was lower in intermediate-severity patches than in low- and high-severity patches $\left(\chi_{1}^{2}=10.8, P=\right.$ 0.001 ; Fig. $1 \mathrm{~A})$, and did not differ between low- and high-severity patches $\left(\chi_{1}^{2}=0.01, P=\right.$ 0.79 ). Daily nest predation rates increased as the breeding season progressed in both years $\left(\chi_{1}^{2}=3.8, P=0.05\right)$, but did not differ either between postfire years $\left(\chi_{1}^{2}=3.0, P=0.083\right)$ or among nests differing in concealment $\left(\chi_{1}^{2}=0.9\right.$, $P=0.34$ ).

Food availability. Terrestrial arthropod biomass varied by date $\left(F_{1,246}=35.1, P<\right.$ $0.001)$, fire severity $\left(F_{2,246}=3.6, P=0.03\right)$, and year $\left(F_{1,246}=21.2, P<0.001\right.$; date $\times$ year $\times$ severity: $\left.F_{7,246}=3.2, P=0.003\right)$. During the first summer after fire, arthropod biomass was highest in low-severity and lowest in highseverity patches during both sampling periods $\left(F_{3,123}=6.7, P<0.001\right.$, Fig. 1B $)$. Arthropod biomass in each severity category more than doubled from early May to June $\left(F_{2,124}=\right.$ 7.2, $P<0.001$, Fig. 1B). During the second summer after fire, estimated arthropod biomass was higher than the previous year $\left(F_{2,124}=3.8\right.$, $P=0.01)$, and variation in arthropod biomass was not related to burn severity $\left(F_{3,123}=1.2\right.$, $P=0.48)$. During the second postfire year, we found no evidence for within-season variation in arthropod biomass in forest patches burned at different severities $\left(F_{3,123}=0.9, P=0.67\right)$.

Territory density and breeding status. All territorial males successfully paired with females independent of burn severity and in both years of the study. We found no difference in the average pairing date for male juncos in areas that differed in burn severity (severity: $F_{2,58}=2.5, P=0.09$; year: $F_{1,58}=2.2, P=$ $0.14)$. Territories sometimes partly overlapped, and did not encompass $100 \%$ of the study area in either year. Territory sizes were unrelated to burn severity $\left(F_{2,104}=1.9, P=0.15\right)$, but territories were significantly larger during the first year after fire $\left(F_{1,104}=4.0, P=0.05\right.$; severity $\times$ year:
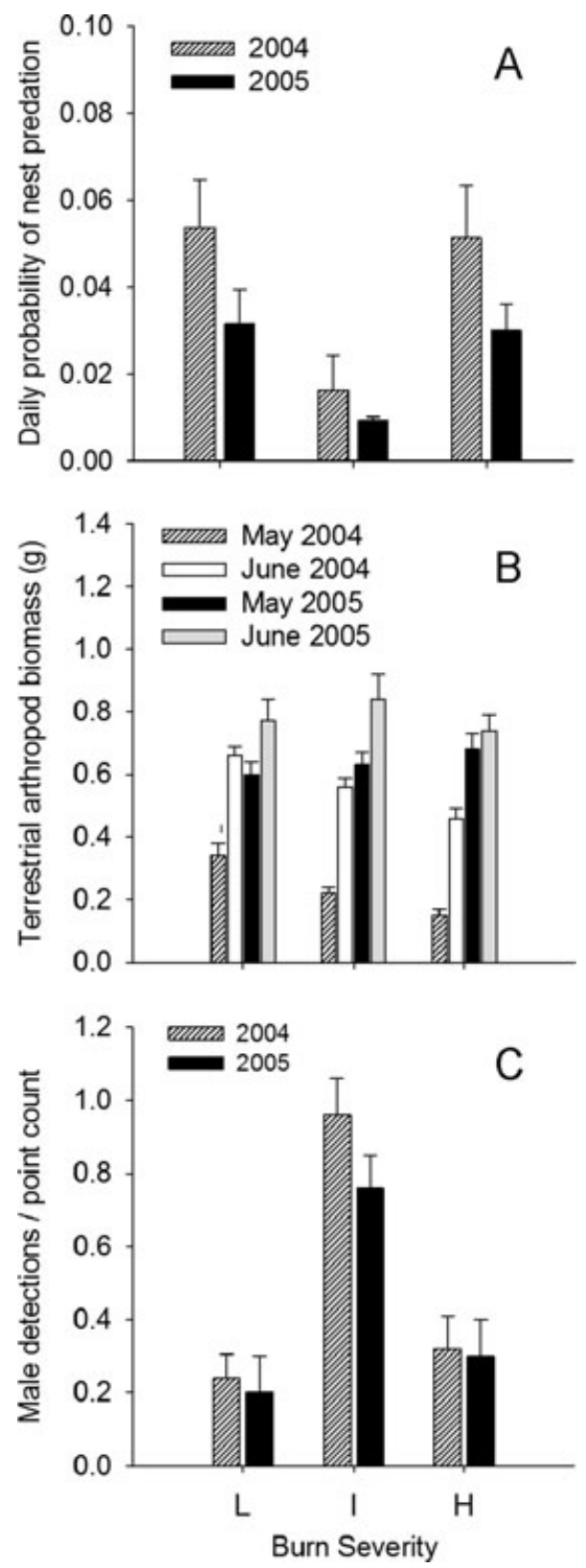

Fig. 1. Variation in the (A) daily probability of predation of Dark-eyed Junco nests, (B) terrestrial arthropod biomass ( $\mathrm{g} /$ trap array), and (C) number of male juncos detected per point count across forest patches burned at different severities ( $\mathrm{L}=$ low, $\mathrm{I}=$ intermediate, and $\mathrm{H}=$ high). Data were collected within the boundaries of the Black Mountain fire of 2003 near Missoula, Montana. Marginal means are presented with the standard error (bars). 
Table 1. Estimates of mean (SE) territory size and density of Dark-eyed Juncos in forest patches burned at different severities.

\begin{tabular}{lllll}
\hline & & \multicolumn{3}{c}{ Burn severity } \\
\cline { 3 - 5 } Year & \multicolumn{1}{c}{ Variable } & \multicolumn{1}{c}{ Low } & Intermediate & High \\
\hline 2004 & Territory size (ha) & $1.60(0.18)$ & $1.73(0.14)$ & $1.88(0.17)$ \\
& Density (territories/ha) & 0.58 & 0.65 & 0.59 \\
2005 & Territory size (ha) & $1.66(0.17)$ & $1.52(0.12)$ & $1.64(0.15)$ \\
& Density (territories/ha) & 0.73 & 0.76 & 0.69 \\
\hline
\end{tabular}

$F_{2,104}=1.7, P=0.18$, Table 1$)$. Density of territories was similar among areas that differed in burn severity during both postfire years (Table 1).

Detections of singing males. We detected the most singing males in intermediateseverity plots in both years (severity: $F_{2,54}=$ 16.9, $P<0.001$; year: $F_{1,54}=1.2, P=0.28$; year $\times$ severity: $\left.F_{2,54}=0.2, P=0.79\right)$. However, the number of detections did not differ between low- and high-severity patches $\left(F_{2,36}=1.5, P=\right.$ 0.45; Fig. 1C).

\section{DISCUSSION}

Junco detections were consistently highest in forest patches that burned with intermediate severity. Although traditional population models would indicate that differences in detection probability among habitats exposed to different burn severity reflect actual differences in abundance (Penteriani 2003, Goretskaia 2004), we found no differences among treatments in either territory size or density. Instead, our detection of more singing males in the habitat with the lowest nest predation rates (intermediate burn severity) suggests that males sang at higher rates in that habitat. Similarly, Fontaine and Martin (2006) found that reduced nest predation rates (resulting from the experimental removal of predators) led to an increase in singing rates by males in several species of songbirds.

A number of factors can influence singing rates of male songbirds, including differences in density (e.g., Goretskaia 2004) and pairing status. However, territory densities and pairing dates did not differ among plots that burned with high, intermediate, and low severity in our study. Thus, the greater singing activity of male Dark-eyed Juncos in plots with the lowest rates of nest predation may simply reflect a tendency for birds to be more active in safer environments (Martin et al. 2000, Fontaine and Martin 2006). Male juncos may invest more energy in singing at the onset of the breeding season in habitats with lower predation risk because they are more likely to benefit both from the successful energetic investment in their first brood and by the opportunity to raise a second brood.

Variation in the abundance of detected males did not reflect food availability in our study. In other systems, however, food availability has been shown to influence singing rates (Gottlander 1987, Grava and Otter 2009). The absence of any relationship between food availability and song detection rate in our study could indicate that food availability does not energetically constrain the frequency of singing, or that we did not adequately quantify the correct food niche of adult juncos. However, in a study conducted at our study site during the same time period as our study, junco clutch size was found to be correlated with spatial and temporal variation in food availability (Robertson 2009). Such results suggest that food availability can limit junco reproductive output, but has less influence on male singing rates than the risk of nest predation. Food may be the ultimate "bottom-up" energetic limitation on organisms, but our results highlight the importance of "top-down" ecological factors such as predation in determining how organisms allocate that energy.

Additional factors, such as paternal effort (Greig-Smith 1982, Welling et al. 1997) and social rank (Otter et al. 1997), may have also influenced the singing behavior of juncos in our study. The ability of males to sing depends on both competitive ability and habitat quality (van Oort et al. 2007). Although we were unable to control for social status and condition, all males successfully paired and point counts were conducted prior to the nestling period (when provisioning nestlings might influence 
male singing rates). Dense vegetation can also reduce the ability of observers to detect birds that are both singing and present through sound attenuation (e.g., Slabbekoorn and Smith 2002) and, in our study, should have resulted in more individuals being detected in the habitat with low vegetation density and complexity (highseverity), but this was not the case. Male singing may also have been influenced by the need to avoid detection by predators, for example, if singing attracts predators of adults (Ward and Slater 2005, Campos et al. 2009) and the abundance of predators of adult juncos varied systematically among burn severities.

Our results are consistent with the hypothesis that the risk of nest predation is an important factor shaping detections during point counts. In contrast, variation in food availability appeared unrelated to the detection of territorial males. From a methodological point of view, these results are important because they illustrate that spatial variation in the risk of nest predation can substantially bias estimates of relative abundance independent of the effects of nest predation on density per se (e.g., Fontaine and Martin 2006). A higher density of individuals in a particular habitat is often used as an index of habitat quality, but, in our postfire landscape, junco density estimates based on aural survey data would have been biased upward in habitats with relatively high reproductive success independent of bird density (see also Van Horne 1983). Ultimately, the effects of food and predation on singing behavior may differ among species with different life-history strategies and depend on the natural variability in these factors that population experience. Consequently, food limitation may influence singing behavior more than nest predation in other systems (e.g., those where nest predation risk is similar across habitats).

Our results have implications for efforts to monitor terrestrial landbirds in postfire habitats, and more generally for monitoring efforts influenced strongly by male singing behavior (e.g., dense habitat types where visual identification is difficult). Additional study is needed to identify the relative importance of these and other sources of variation in detectability because each can undermine assumptions about equal detectability among habitat categories. Our results suggest that accurate estimates of detectability across different habitats will require researchers to incorporate not just distance, but other relevant covariates into models. Unfortunately, sample sizes will generally preclude controlling for many covariates simultaneously, so reliable estimates of bird density will continue to be a challenge.

\section{ACKNOWLEDGMENTS}

We thank the Lolo National Forest and the U.S. Forest Service for funding and logistical support. Thanks also to R. Fletcher for input and logistical support on this study, and to B. Crees, M. Hethcoat, K, Asakawa, and A. Lawrence for data collection. This work complied with the current laws governing animal research in the United States. JJF was supported by an ECOS fellowship from an NSF GK-12 grant (03-38165) to the University of Montana and NSF Grant No. DEB-0543178 to T. Martin.

\section{LITERATURE CITED}

Alldoredge, M. W., T. R. Simons, and K. H. PolLOCK. 2007a. Factors affecting aural detections of songbirds. Ecological Applications 17: 948-955.

SHRINER. 2007b. Multiple-species analysis of point count data: a more parsimonious modeling framework. Journal of Applied Ecology 44: 281-290.

ARno, S. F., AND S. Allison-Bunnel. 2002. Flames in our forest: disaster or renewal? Island Press, Washington, DC.

Campos, D. P., L. A. Bander, A. Raksi, and D. L. BLUMSTEIN. 2009. Perch exposure and predation risk: a comparative study in passerines. Acta Ethologica 12: 93-98.

Carey, A. B., V. E. Castellano, C. Chappell, R. Kuntz, R. W. Lundquist, B. G. Marcot, N. S. KIM, AND P. Sullivan. 1990. Training guide for bird identification in Pacific Northwest Douglasfir forests. General Technical Report PNW-GTR260, U.S. Department of Agriculture, Forest Service, Pacific Northwest Research Station, Portland, OR.

CLARK, J., AND T. BOBBE. 2006. Using remote sensing to map and monitor fire damage in forest ecosystems. In: Forest disturbance and spatial patterns, GIS and remote sensing approaches (M. Wilder AND S. Franklin, eds.), pp. 113-132. Taylor and Francis, London, UK.

Diefenbach, D. R., M. R. Marshall, J. A. Mattice, AND D. W. BRAUNING. 2007. Incorporating availability for detection in estimates of bird abundance. Auk 124: 96-106.

DieHL, B. 1981. Bird populations consist of individuals differing in many respects. Studies in Avian Biology 6: 225-229.

Emlen, J. T., AND M. J. Dejong. 1981. The application of song detection threshold distance to census operations. Studies in Avian Biology 6: 346-352.

Farnsworth, G., K. H. Pollock, J. D. Nichols, T. R. Simons, J. E. Hines, AND J. R. Sauer. 2002. A removal model for estimating the detection probability 
during point counts divided into time intervals. Auk 119: 414-425.

Fontaine, J. J., AND T. E. Martin. 2006. Habitat selection responses of parents to offspring predation risk: an experimental test. American Naturalist 168: 811-819.

Fretwell, S. D. 1972. Populations in a seasonal environment. Princeton University Press, Princeton, NJ.

GoretskaiA, M. I. 2004. Song structure and singing behavior of Willow Warbler Prylloscopus trochilus acredula in populations of low and high density. Bioacoustics 14: 183-195.

GOTTLANDER, K. 1987. Variation in the song rate of the male Pied Flycatcher Ficedula hypoleuca: causes and consequences. Animal Behaviour 35: 1037-1043.

Grava, A., And K. A. OTTER. 2009. Supplemental feeding and dawn singing in Black-capped Chickadees. Condor 111: 560-564.

Greig-Smith, P. W. 1982. Song rates and parental care by individual male Stonechats Saxicola torquata. Animal Behaviour 30: 245-252.

HABECK, J. R., AND R. W. MuTCH. 1973. Fire-dependent forests in the northern Rocky Mountains. Quaternary Research 3: 408-424.

HANSKI, I. K., AND A. LAURILA. 1993. Variation in song rate during the breeding cycle of the Chaffinch, Fringilla coelebs. Ethology 93: 161-169.

HOCHACHKA, W. 1990. Seasonal decline in reproductive performance of Song Sparrows. Ecology 71: 1279_ 1288.

Hoi-Leitner, M., H. Nechtelberger, And H. Hoi. 1995. Song rate as a signal for nest site quality in Blackcaps (Sylvia atricapilla). Behavioral Ecology and Sociobiology 37: 399-405.

HostetTer, D. R. 1961. Life history of the Carolina Junco Junco hyemalis carolinensis Brewster. Raven 32: 97-145.

JoHnSON, D. H. 2008. In defense of indices: the case of bird surveys. Journal of Wildlife Management 72 : 857-868.

Kessler, W. B., And K. A. Milne. 1982. Morning versus evening detectability of southeast Alaskan birds. Condor 84: 447-448.

Key, C. H., And N. C. Benson. 2005. Landscape assessment: ground measure of severity, the Composite Burn Index; Remote sensing of severity, the normalized Burn Ratio. In: FIREMON: Fire effects monitoring and inventory system (D. C. Lutes, R. E. Keane, J. F. Caratti, C. H. Key, N. C. Benson, and L. J. Gangi, eds.). pp. LA1-LA51, General Technical Report RMRS-GTR-164-CD:LA1-LA51, USDA Forest Service, Rocky Mountain Research Station, Fort Collins, CO.

Komdeur, J., AND K. H. KaTS. 1999. Predation risk affects the trade-off between nest guarding and foraging in Seychelles Warblers. Behavioral Ecology 10: 648658.

Krefting, L. W., And C. E. Ahlgren. 1974. Small mammals and vegetation changes after fire in a mixed conifer-hardwood forest. Ecology 55: 1391-1398.

Marques, T. A., L. Thomas, S. G. Fancy, and S. T. BUCKLAND. 2007. Improving estimates of bird density using multiple covariate distance sampling. Auk 124: 1229-1243.
Martin, T. E., And G. R. Guepel. 1993. Nestmonitoring plots: methods for locating nests and monitoring success. Journal of Field Ornithology 64 : 507-519.

- J. SCOTT, AND C. MENGE. 2000. Nest predation increases with parental activity: separating nest site and parental activity effects. Proceedings of the Royal Society of London B 267: 2287-2294.

Mccallum, A. A. 2005. A conceptual guide to detection probability for point counts and other count-based methods. In: Bird conservation implementation and integration in the Americas: Proceedings of the Third International Partners in Flight conference (C. J. Ralph and T. D. Rich, eds.), pp. 754-761. U.S. Department of Agriculture Forest Service, GTRPSW-191, Albany, CA.

MCSheA, W. J., AND J. H. Rappole. 1997. Variable song rates in three species of passerines and implications for estimating bird populations. Journal of Field Ornithology 68: 367-375.

MERILÄ, J., AND J. SORJONEN. 1994. Seasonal and diurnal patterns of singing and song-flight activity in Bluethroats (Luscinia svecica). Auk 111: 556562.

NiLsson, J. A. 1989. Causes and consequences of natal dispersal in the Marsh Tit (Parus palustris). Journal of Animal Ecology 58: 619-636.

Nolan, V. Jr., E. D. Ketterson, D. A. Cristol, C. M. Rogers, E. D. Clotfelter, R. C. Titus, S. J. SCHOECH, AND E. SNAJDR. 2002. Dark-eyed Junco (Junco hyemalis). In: The Birds of North America, No. 716 (A. Poole AND F. Gill, eds.). The Birds of North America, Inc., Philadelphia, PA.

Nystrom, K. G. K. 1997. Food density, song rate, and body condition in territory-establishing Willow Warblers (Phylloscopus trochilus). Canadian Journal of Zoology 75: 47-58.

O'CONNOR, R. J., AND R. K. HiCKS. 1980. The influence of weather conditions on the detection of birds during common birds census fieldwork. Bird Study 27: $137-151$

Odum, E. P., AND E. J. KuEnZler. 1955. Measurement of territory and home range size in birds. Auk 72: $128-137$.

OtTer, K., B. Chruszcz, and L. Ratcliffe. 1997. Honest advertisement and song output during the dawn chorus of Black-capped Chickadees. Behavioral Ecology 8: 167-173.

Penteriani, V. 2003. Breeding density affects the honesty of bird vocal displays as possible indicators of male/territory quality. Ibis 145: E127-E135.

Platt, W. J., AND J. H. ConNell. 2003. Natural disturbances and directional replacement of species. Ecological Monographs 73: 507-522.

Ralph, C. J., G. R. Geupel, P. Pyle, T. E. Martin, and D. F. DESANTE. 1993. Handbook of field methods for monitoring landbirds. General Technical Report PSWGTR-144, Pacific Southwest Research Station, Forest Service, U.S. Department of Agriculture, Albany, CA.

, J. R. Sauer, AND S. Droege (eds.). 1995. Monitoring bird populations by point counts. General Technical Report PSW-GTR-149, U.S. Department of Agriculture, Forest Service, Albany, CA. 
Reynolds, R. T., J. M. SCOTt, and R. A. Nussbaum. 1980. A variable circular-plot method for estimating bird numbers. Condor 82: 309-313.

Robertson, B. A. 2009. Nest site selection in a postfire landscape: do parents make tradeoffs between microclimate and predation risk? Auk 126: 500510.

Ryan, K. C., AND N. V. NosTE. 1985. Evaluating prescribed fires, In: Proceedings of the symposium and workshop on wilderness fire, pp. 230-238. USDA Forest Service, General Technical Report INT-182, Missoula, MT.

SAS Institute. 1999. SAS/STAT user's guide, version 8. SAS Institute, Cary, NC.

Sauer, J. R., B. G. Peterjohn, And W. A. Link. 1994. Observer differences in the North American Breeding Bird Survey. Auk 111: 50-62.

SCHIECK, J. 1997. Biased detection of bird vocalizations affects comparisons of bird abundance among forested habitats. Condor 99: 179-190.

Scott, J. M., F. L. Ramsey, and C. B. Kepler. 1981. Distance estimation as a variable in estimating bird numbers from vocalizations. Studies in Avian Biology 6: 334-340.

SHAFFER, T. L 2004. A unified approach to analyzing nest success. Auk 121: 526-540.

SHEILDS, W. M. 1977. The effect of time of day on avian census results. Auk 94: 380-383.

ShorT, K.C., AND J. F. Negrón. 2003. Arthropod responses: a functional approach. In: Ecological restoration of southwestern ponderosa pine forests (P. Friederici, ed.), pp. 286-305. Island Press, Washington, DC.

SlabbeKoorn, H., and T. B. Smith. 2002. Habitatdependent song divergence in the Little Greenbul: an analysis of environmental selection pressures on acoustic signals. Evolution 56: 1849-1858.

Stuart-Smith, A. K., AND J. P. HaYes. 2003. Influence of residual tree density on predation of artificial and natural songbird nests. Forest Ecology and Management 183: 159-176.

Titus, R. C., C. R. Chandler, E. D. Ketterson, And V. NOLAN, Jr. 1997. Song rates of Dark-eyed Juncos do not increase when females are fertile. Behavioral Ecology and Sociobiology 41: 165-169.

Thomas, R. J., AND I. C. CuThill. 2002. Body mass regulation and the daily singing routines of European Robins. Animal Behaviour 63: 285-295.

Thompson, W. L. 2002. Towards reliable bird surveys: accounting for individuals present but not detected. Auk 119: 18-25.

Turner, M. G., W. H. Romme, And D. B. Tinker. 2003. Surprises and lessons from the 1988 Yellowstone fires. Frontiers in Ecology and the Environment 1: 351358.

VAn Horne, B. 1983. Density as a misleading indicator of habitat quality. Journal of Wildlife Management 47: 893-901.

VAn OORT, H., K. A. Otter, K. Fort, and Z. MCDONELL. 2007. Habitat, dominance and the phenotypic quality of male Black-capped Chickadees. Condor 109: 88-96.

Ward, S., and P. J. B. Slater. 2005. Raised thermoregulatory costs at exposed song posts increase the energetic cost of singing for Willow Warblers, Phylloscopus trochilus. Journal of Avian Biology 36: 280-286.

Welling, P. P., S. O. RytKonen, K. T. Koivula, and M. I. ORELL. 1997. Song rate correlates with paternal care and survival in Willow Tits: advertisement of male quality? Behaviour 134: 891-904.

WIKARS, L.-O., AND J. SCHMIMEL. 2001. Immediate effects of fire-severity on soil invertebrates in cut and uncut pine forests. Forest Ecology and Management 141: 189-200.

WILSON, D. M., AND J. BART. 1985. Reliability of singing bird surveys: effects of song phenology during the breeding season. Condor 87: 69-73.

ZwOlaK, R., AND K. R. Foresman. 2007. Effects of a stand-replacing fire on small-mammal communities in montane forest. Canadian Journal of Zoology 85: $815-822$. , AND . 2008. Deer mouse demography in burned and unburned forest: no evidence for sourcesink dynamics. Canadian Journal of Zoology 86: 8391. 